\title{
Is dental extraction a risk factor for contracting HCV infection: Abs, RNA and genotype detection
}

\author{
Waqar Al-Kubaisy ${ }^{1,4^{*}}$, Redhwan A. Al-Naggar ${ }^{1,4}$, Nik Shamsidah NI ${ }^{1}$, Yuri V. Bobryshev ${ }^{2}$ and Mustafa Waseem Al-Kubaisy ${ }^{3}$ \\ *Correspondence:Waqar_abd@yahoo.co.uk

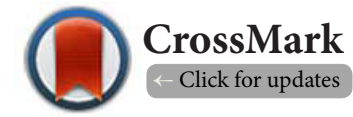 \\ 'Population Health and Preventive Medicine, Faculty of Medicine, Universiti Teknologi MARA, Malaysia. \\ ${ }^{2}$ Faculty of Medicine, University of New South Wales and St Vincent's Hospital Sydney Sydney 2052, Nsw, Australia. \\ ${ }^{3}$ Director of Dental Health Clinic, Singar, Ninawa, Ministry of Health, Iraq. \\ ${ }^{4}$ Drug Discovery and Health Community of Research, Universiti Teknologi MARA (UiTM), 40450 Shah Alam, Selangor, Darul Ehsan, \\ Malaysia.
}

\begin{abstract}
Background: The medical risk factor associated with hepatitis $\mathrm{C}$ virus (HCV) infection such as blood transfusion and surgery had been intensely studied in many countries. Up to $40 \%$ of patients infected with HCV may have non identifiable routes of viral acquisition. Dental extraction may be one of these risk factors. The purpose of the present study was to determine the existence of infection and the predominated HCV genotype among subjects with dental extraction.

Material and methods: A case-control study involving pregnant women with and without history of dental extraction ( $\mathrm{n}=776, \mathrm{n}=2715$, respectively). HCV antibodies (anti-HCV) were tested using subsequently third generation enzyme immunoassay (EIA-3) and immunoblot assay (Lia Tek-111). In addition 94 serum samples were subjected to molecular analysis using RT-PCR and DNA enzyme immunoassay (DEIA) method for HCV-RNA and genotypes.

Results: Anti-HCV seroprevelance was significantly higher (6.3\%) among cases with dental extraction (cases) than their counter control group (control) (2.63\%) $(\mathrm{p}=0.00001)$. Dental extraction act as a risk factor for $\mathrm{HCV}$ infection $(\mathrm{OR}=2.73 ; 95 \% \mathrm{CI}=1.8-3.9)$. $\mathrm{HCV}-\mathrm{RNA}$ was found to be significantly higher $(74.6 \%)$ in cases than $(38.7 \%)$ control group $(\mathrm{p}=0.0016)$. No significant association between HCV genotypic and the history of tooth extraction but HCV-1b showed higher rate (90\%) among dental extraction cases.

Conclusion: Our study showed that dental extraction acts as a risk factor for acquiring HCV. Complete sterilization and cleaning of equipment is necessary.
\end{abstract}

Keywords: Hepatitis C virus (HCV), dental extraction, risk factor, HCV genotypes

\section{Introduction}

Hepatitis $\mathrm{C}$ virus $(\mathrm{HCV})$ is recognized as an important global disease, with more than 170 million people are chronically infected. Hepatitis C is generally asymptomatic with up to $80 \%$ of infected cases which will progress to persistent infection. About $15-20 \%$ of chronic HCV infection progressed to cirrhosis and 1 to $4 \%$ are found to be an annual risk of developing hepatocellular carcinoma within 20-30 years [1-3]. Blood, blood-products and intravenous drug abuse (IV) are related with the transmission of this virus. Probabilities due to sexual and interfamilial transmission are somehow low. In addition, tattoo may also consider as suspected factors in the transmission [4]. Transmission of HCV has been mainly related to intravenous drug use since blood products transmission has decreased in most developed countries [5]. Surprisingly, Nokhodian and his colleagues (2012) stated that HCV transmission may also be acquired through non-parenteral and non-sexual routes [6]. Indeed, several authors estimated that up to $40 \%$ of patients infected with HCV may have non identifiable routes of viral acquisition $[3,7,8]$. Therefore, identification and elimination of other possible transmission routes will play a significant role in HCV infection restriction $[\mathbf{9}, \mathbf{1 0}]$. Despite its higher prevalence and transmissibility, viral hepatitis $C$, has received far less global attention than HIV. At the WHO's 63 $3^{\text {rd }}$ World Health Assembly in May 2010, a resolution was passed to establish "goals and strategies for disease control, increasing education

() 2014 Al-Kubaisy et al; licensee Herbert Publications Ltd. This is an Open Access article distributed under the terms of Creative Commons Attribution License (http://creativecommons.org/licenses/by/3.0). This permits unrestricted use, distribution, and reproduction in any medium, provided the original work is properly cited. 
Al-Kubaisy et al. Oral Biology and Dentistry 2014,

and promoting screening and treatment" of people infected with HCV [2].

Hahné et al., (2013) documented that screening programmes for chronic HCV infection is potential in primary and secondary prevention and might lead to other plausible sources of transmission [11]. However, existing HCV screening programmes in Iraq are limited to primary prevention namely blood donors. Secondary prevention of HCV is achievable by identifying the chronic carriers, who may benefit from treatment [11]. To date, there is no available vaccine for $\mathrm{HCV}$ prevention. Hence, identifying the probable routes of transmission and eliminating them, including dental treatment is an important way to reduce HCV infection [10-14].

The presence of viral hepatitis $C$ particles in oral fluids has been demonstrated by many authors and this may indicate that transmission via saliva and gingival cervical fluid might occur $[15,16]$. Dentists and dental health care workers are at a high risk of infection with HCV during their daily occupational exposures $[15,16]$. Similarly, they can infect their patients by such agents if adequate infection control is not implemented $[10,17]$. Coates et al., (2000) reported that dental caries and number of teeth missing from patients with hepatitis $\mathrm{C}$ infection were significantly higher and worse than other patients in general [18]. Several authors reported that, HCV was the strongest predictor of patients with poor oral health $[17,19]$.

Six major genotypes (1-6) of HCV with various geographical distributions, studied population and transmission risk factors have been identified (Paraboni et al., 2012, Modi and Liang 2008, Simmond 1997) $[\mathbf{5 , 2 0 , 2 1 ]}$. Determining the genotype of $\mathrm{HCV}$ is an important tool, for diagnosis and epidemiological purposes that may allow tracing of infectious source and will shed light on the rout of HCV transmission [22]. Therefore, the recognition of HCV-RNA as well as specific genotypes will be important for optimal diagnostic test of HCV-RNA. The latter is increasingly used as a measure of infectivity. To date there has been no definite conclusion on the role of dental treatment in $\mathrm{HCV}$ transmission. Following dental extraction, HCV acquisition is still controversial. Therefore, this study was conducted to determine if dental extraction acts as risk factor for HCV infection and to identify the infectivity and most predominant HCV genotypes among subjects with dental extraction.

\section{Materials and methods}

A case -control study was conducted among pregnant women in Baghdad. Nineteen of 121 healthcare clinics providing dental health services were chosen randomly. The study population consists of 776 pregnant women with history of dental extraction and 2715 with no such history. All the participants are in their third trimester, in good health and not having Jaundice. All cases having dental extraction of at least 6 month prior to the study were interviewed focusing on history and place of tooth extraction. Only respondents with informed consent were interviewed using a structured questionnaire and a serum sample was taken for analysis.

Serum sample obtained from each participant was dispensed in two screw capped frozen tubes, stored at $-20^{\circ} \mathrm{C}$ and $-70^{\circ} \mathrm{C}$ for antibody testing and molecular analysis respectively. Initial screening of $\mathrm{HCV}$ antibody was carried out using third generation enzyme immunoassay (EIA-3). The positive results were confirmed by using the third generation immunoblot assay (Lia Tek-111). This test yield to 3 results interpretation (Positive, Indeterminate or Negative). Only Lia-Tek III reactive serum sample was considered as positive $\mathrm{HCV}$ antibodies serum. On the other hand, a total of 94 (stored at $-70^{\circ} \mathrm{C}$ ) comprising of 64 positive, 20 indeterminate \& 10 negative Lia Tek-111 serum samples were transferred to laboratories of Sorin Diagnostica (Sallugia, Italy) for molecular analysis using the RT-PCR and DNA enzyme immunoassay (DEIA) method. Each sample was subjected to extraction of RNA followed by synthesis of complementary DNA (cDNA), subsequently amplification of newly synthesized CDNA was carried out. Detection of RNA and genotypes of HCV was done using DEIA method. This method is based on hybridization of the complementary (CDNA) with a single standard DNA probe coated on the wall of the microtiter plate wells with streptavidin-biotin band. Detection of hybridization was achieved by the use of anti-double stranded DNA monoclonal antibody. Finally, the result was obtained by spectrophotometer. Classification was done using the Simmond's Nomenclature for HCV genotypic classification as proposed by international HCV collaboration group 1994. All the laboratory procedures were done according to the manufacturer's instructions. Descriptive and statistical analysis using SPSS 20 was done. Univariate analysis, odds ratios (ORs) and $95 \% \mathrm{Cls}$ were calculated, considering $\mathrm{p}<$ 0.05 as significant.

\section{Results}

A total number of 3491 pregnant women participated in this study. Out of the 776 cases, 451 and 325 had their tooth extraction at government and private dental clinics respectively. HCV antibody were positive in $48(6.2 \%)$ and $64(2.36 \%)$ in cases and control group, respectively. HCV seropositive rate was significantly higher among women with history of tooth extraction compared to the control group ( $p=0.00001$ ). Our study also showed that women attending government dental clinics had higher (7.5\%) anti-HCV seropositive status compared to (4.3\%) of those attending private clinics. However, the difference was not statistically significant $(p=$ 0.06). Interestingly, using univariate analysis, dental extraction proved to be a significant risk factor for acquiring $\mathrm{HCV}$ infection $(\mathrm{OR}=2.7,95 \%$ C. I: $1.888-3.95)$ in both government $(\mathrm{OR}=3.377$, $95 \%$ C. I: 2.251-5.066) and private clinics ( $O R=1.865,95 \%$ C. I: 1.043-3.334) (Table 1).

With respect to molecular analysis, out of 94 serum samples, 59 demonstrated HCV-RNA positive. In all 64+ve Lia Tek-111 (48 case and 16 control) 52 showed positive RNA for HCV. None 
of the 10 negative Lia Tek-111 showed positive HCV- RNA. Interestingly 7/20 of indeterminate Lia Tek-111 demonstrated HCV RNA positive. Among 48 women having dental extraction with the positive Lia Tek-111, 42 demonstrated HCV RNA positive, while $5 / 10$ of the indeterminate Lia Tek-111 showed RNA positive. On the other hand, 10/16 of the control group with the positive Lia Tek-111, showed HCV-RNA positive and 2/10 indeterminate showed RNA positive (Table 2).

Out of 59 HCV-RNA seropositive, 57 were genotyped and two HCV- RNA positive could not be genotyped. Surprisingly the two positive RNA were related to indeterminate Lia Tek111 result. Five genotypes and subtypes $(1,1 a, 1 b, 4$, and $3 a)$ were detected in this study, with single infection $(1,1 a, 1 b$, and 4 ) or dual infection $(1 \& 4,1 b \& 4,3 a \& 4)$. The predominant genotype circulating was HCV-4 (29/57), followed by HCV-1b (20/57). HCV-3a was the lowest. Interestingly the highest HCVgenotype prevalent among women with dental extraction was HCV-1b (90\%) (18/20), followed by HCV-4 (82.7\%) (24/29) and genotype HCV-3a (66.6\%) (2/3) was the lowest (Table 3).

\section{Discussion}

Worldwide more than 170 million people are infected with HCV, causing over 350,000 deaths annually [1]. In developed countries, $\mathrm{HCV}$ is transmitted mainly through intra venous drug abuse whereas in many developing countries including Iraq blood transfusion and unsafe medical injections are predominant sources of infection [2]. Some healthcare interventions may act as risk factors for HCV infection and dental procedures may be one of these [10]. Hence, viral hepatitis infection in dentistry is an important issue. To date there is no definitive conclusion on the role of dental procedures in HCV transmission. Potential risk of HCV transmission through dental procedure was evaluated in our study to determine whether HCV infection is associated with dental extraction. We found that there was a significant association between dental extraction and increased anti-

Table 1. Anti-HCV antibody seropositive according to respondents and type of Dental Clinics in Baghdad.

\begin{tabular}{|c|c|c|c|c|c|c|c|}
\hline \multirow[t]{2}{*}{ Respondents } & \multirow[t]{2}{*}{ Total } & \multicolumn{2}{|c|}{ Anti-HCV } & \multirow[t]{2}{*}{$\chi^{2}$} & \multirow[t]{2}{*}{$\mathbf{p}$} & \multirow[t]{2}{*}{ OR } & \multirow[t]{2}{*}{ 95\% CI } \\
\hline & & $+\mathrm{ve}$ & -ve & & & & \\
\hline Cases & 776 & $48(6.2 \%)$ & 728 & \multirow{2}{*}{27.26} & \multirow{2}{*}{0.00001} & \multirow{2}{*}{2.731} & \multirow{2}{*}{$1.89-3.95$} \\
\hline Control & 2715 & $64(2.36 \%)$ & 2651 & & & & \\
\hline Government Dental clinic & $451(58.12 \%)$ & $34(7.53 \%)$ & -- & \multirow{2}{*}{3.4} & \multirow{2}{*}{0.06} & 3.38 & $2.25-5.1$ \\
\hline Private Dental clinic & $325(41.88 \%)$ & $14(4.3 \%)$ & -- & & & 1.87 & $1.04-3.33$ \\
\hline
\end{tabular}

Table 2. HCV-RNA \& Genotypes distribution according to Lia Tek-111 result among respondents in Baghdad.

\begin{tabular}{|c|c|c|c|c|c|c|c|c|c|c|c|c|}
\hline \multirow{2}{*}{\multicolumn{2}{|c|}{$\begin{array}{l}\text { Anti-HCV Lia Tek-111 } \\
\text { status in subject }\end{array}$}} & \multirow{3}{*}{$\begin{array}{l}\text { Total } \\
--\end{array}$} & \multicolumn{2}{|c|}{ HCV-RNA* } & \multicolumn{7}{|c|}{ HCV-genotypes/subtypes ${ }^{* *}$} & \multirow{3}{*}{\begin{tabular}{|l|} 
Total \\
--
\end{tabular}} \\
\hline & & & \multirow{2}{*}{\begin{tabular}{|c|}
$-v e$ \\
16
\end{tabular}} & \multirow{2}{*}{\begin{tabular}{|l} 
+ve \\
47
\end{tabular}} & \multirow{2}{*}{$\begin{array}{l}1 \\
--\end{array}$} & \multirow{2}{*}{$\begin{array}{l}\mathbf{a} \\
--\end{array}$} & \multirow{2}{*}{$\begin{array}{c}b \\
--\end{array}$} & \multirow{2}{*}{$\begin{array}{l}4 \\
--\end{array}$} & \multirow{2}{*}{$\begin{array}{l}184 \\
--\end{array}$} & \multirow{2}{*}{$\begin{array}{l}\mathrm{b} \& 4 \\
--\end{array}$} & \multirow{2}{*}{$\begin{array}{l}3 a \& 4 \\
--\end{array}$} & \\
\hline Case $=63$ & -- & & & & & & & & & & & \\
\hline & +ve Lia Tek-111 & 48 & 6 & $42(87.5 \%)$ & 3 & 8 & 8 & 10 & 2 & 9 & 2 & 42 \\
\hline & Indeterminate & 10 & 5 & $5(50 \%)$ & 1 & 2 & 1 & 1 & 0 & 0 & 0 & 5 \\
\hline & -ve Lia Tek-111 & 5 & 5 & 0 & -- & -- & -- & -- & -- & -- & -- & -- \\
\hline \multirow[t]{4}{*}{ Control $=31$} & -- & -- & 19 & 12 & -- & -- & -- & -- & -- & -- & -- & -- \\
\hline & +ve Lia Tek-111 & 16 & 6 & $10(62.5 \%)$ & 1 & 3 & 1 & 2 & 1 & 1 & 1 & 10 \\
\hline & Indeterminate & 10 & 8 & $2(20 \%)$ & -- & -- & -- & -- & -- & -- & -- & -- \\
\hline & -ve Lia Tek-111 & 5 & 5 & 0 & 0 & 0 & 0 & 0 & 0 & 0 & 0 & -- \\
\hline Total & -- & 94 & 35 & 59 & 5 & 13 & 10 & 13 & 3 & 10 & 3 & $57^{*}$ \\
\hline
\end{tabular}

${ }^{\star} \chi 2=9.97 ; \mathrm{P}=0.0016 ;{ }^{\star} \mathrm{OR} 4.6595 \% ; \mathrm{C} . \mathrm{I}=1.08-2.69 ;{ }^{*} \chi^{2}=4.07 ; \mathrm{P}=0.53$

Table 3. Percentage of different HCV-genotypes/subtypes among cases with dental extraction.

\begin{tabular}{ll}
\hline HCV genotypes \& subtypes & Percentage \\
\hline HCV-1 & $75 \%$ \\
HCV $1 \mathrm{a}$ & $77 \%$ \\
HCV-1b & $90 \%$ \\
HCV-4 & 82.7 \\
HCV-3a & 66.6 \\
\hline
\end{tabular}


Al-Kubaisy et al. Oral Biology and Dentistry 2014,

HCV seropositivity (6.2\%). In addition, dental extraction acts as a risk factor for acquiring HCV infection (OR 2.73, 95\% C.I. 1.88-3.9). These findings were similar to other study which detected a high prevalence of (22.4\%) anti-HCV seropositivity following dental surgery [23]. Similar studies conducted in Pakistan, Turkey, Morocco, and Italy had reported that dental procedure was one of the major risk factor for HCV transmission [1,4,11,24]. Moreover Ali et al., (2011) indicated that dental procedure is one of the major source of exposure for HCV transmission (39.7\%) followed by injections (16.6\%) and surgical procedures (16.6\%) [24].

In contrast to our finding, several studies in Australia, Romania, Nigeria ,France ,Pakistan, and Iran found that dental procedures was not associated with anti-HCV positivity [10,25-27]. Yildirim et al., (2005) showed a significant detection of HCV-RNA among Turkish HCV patients who underwent dental surgery (77.5\%) compared to the control group (58.3\%) [4]. Ali et al., (2011) in Khyber, Pakistan also found that the prevalence of anti-HCV and active HCV infection among individuals with dental surgery group was $14.28 \%$ [24]. Similarly, the women with dental extraction in our study were not only infected but they were also actively infective and thus could be a source of HCV infection. Our findings showed a significantly high rate of positive HCV- RNA (81\%) in sera of the cases (positive and indeterminate Lia Tek III) with a significant risk of exposure (OR 2.7). The findings are interesting particularly when Hasegawa et al., (2003) found both anti-HCV and HCVRNA in haemostatic gauzes from infected patients referred to dental clinics, even after being kept at room temperature for 24 hours [28]. In addition, about 19\% of the cases in our study demonstrated negative HCV-RNA in their sera. This is consistent with another study [29] which reported that HCV-RNA detection may become negative in 15-30\% of patients during the first 3-6 months, whereas its positivity may continue in others. Dental extraction performed at both government and private clinics may act as a significant risk factor for acquiring HCV infection among cases enrolled in our study. However dental extraction at the government clinics demonstrated a higher risk of exposure (OR 3.3377 95\% C.I 2.25-5.066) compared to that acquired from private clinics (OR 1.865 95\% C.I. 1.043 -3.34). The variations could be attributed to the difference in the socioeconomic status of the attendees at the two types of clinics. In addition, overcrowding in government clinics and fast turnover of patients may contribute for the higher prevalence rate of HCV infection. It is well known that decontamination procedures were highly dependent on availability of electricity for sterilization, availability of spare parts, well trained health care workers, good management and control procedures. Thus lack of one or more, of these essential conditions may result in contamination of injection and/or equipment, which may play a role in the high prevalence of anti-HCV. Besides that, non adherence to guidelines on infection control, use of non disposable or reusable syringes, lack of sufficient sterilization techniques and sharing of personal hygiene objects, may be the factors for $\mathrm{HCV}$ transmission. Due to these reasons, studies done in the US, Western Europe and Australia generally have not reported any association between medical or dental procedures and viral hepatitis infection as there was a good infection control mechanism [10]. Discrepancy in the prevalence of anti HCV antibody may also be related to the different methods used, difference in population socio demographic characteristics and HCV genotype variations. Blood donor screening in return, may play a part in lowering the HCV antibody prevalence rate.

Determining the genotype of HCV is an important tool for diagnosis and epidemiological analysis. These may allow tracing of infectious sources and determine the route of HCV transmission [22]. In addition, HCV genotype is a known predictive factor for antiviral treatment response. There are clear evidence, indicating that genotypes 1 and 4 are associated to poor interferon response, either in single therapy or combined with ribavirin, the opposite being true for genotypes 2 and 3 [5]. It is well recognised, that some HCV genotypes such as 1a, 1b, 2a, 2b, 2c show a broad distribution worldwide. By contrast, genotypes 5 or $6 a$ have only been found in very specific region, whereas genotype 4 is found predominantly in the Middle East and Central Africa [21,30]. Using RT-PCR/DEIA assay, our study detected that the most circulating HCV-genotypes among Iraqi pregnant women are $4,1 b, 1 a, 1$, and $3 a$ (in decreasing order). All were presented in a single pattern except $\mathrm{HCV}-3 \mathrm{a}$, or in a mixed pattern, except HCV-1a. Results of our study were in accordance with that of Alfaleh and Ramia (1997) who demonstrated the same pattern of HCV genotype distribution, with HCV-4 as the predominated genotype followed by HCV-1b and $1 \mathrm{a}$ among Saudi patients [31]. This finding is in accordance with other studies $[\mathbf{2 1}, \mathbf{3 2}]$ stating that HCV-4 was the most predominant genotype in the Middle East. Moreover several studies reported that HCV-4 and its subtypes $4 a, 4 b, 4 c$ and $4 d$, were found to be the predominant genotype among Egyptian population $[\mathbf{2 1}, \mathbf{3 3}]$. This is interesting as there was a considerably high proportion of Egyptians who resided in Iraq until 1990, and may have contributed to high prevalence of HCV-4 in Iraq via blood donation.

Although HCV-4 is predominant among Iraqi population, we detected that HCV $-1 \mathrm{~b}$ was the predominant genotype among the cases with dental extraction. This is similar to studies done in Turkey [4] Japan [17] and South Korea [10] with genotype 1 or $1 \mathrm{~b}$ seen in a significantly high ratio among those with history of dental extraction. However studies in Brazil and Lybia detected that history of dental procedure increased the risk for infection by genotype $2[5,34]$. Our study reflected a notable point, where the predominate circulating genotype (HCV-4) of Iraqi community was always present in mixed infection. This finding supported by Lin et al. 1996 in Taiwan which express the significance of nosocomial transmission of HCV [35]. The mixed infection could be due to multiple exposure to a single or different source of $\mathrm{HCV}$ 
infection. However, the presence of a single infection may not rule out possible existence of a previous HCV genotype mixed infection as Love et al., (1996) explained that the strain with a high replication competent genotype supersedes the earlier onesor the first infected genotypes prevent the establishment of other genotypes, leading to a single infection [36]. Pawlotsky et al., (1997) showed that HCV genotype had an influence on the antibody response in patients with chronic infection [37]. This hypothesis was confirmed by result of our study which showed solely a single HCV genotypic (25\%) among indeterminate LiaTek-III.

A striking finding of 2 untypable HCV-RNA with indeterminate LiaTek-III, with no history of dental extraction supported reports by several authors, who demonstrated untypable HCV- RNA [38-42]. The untypability HCV RNA was explained by several authors, low level of viremia $[\mathbf{3 8 , 4 0 ]}$, degradation of the viral genome due to inadequate storage $[39,43]$, inappropriate annealing between the RT-PCR product and HCV genotype specific probe [42], or the viral RNA may hitherto belong to unrecognized HCV genotype [41].

\section{Conclusion}

Our study showed that dental extraction acts as a risk factor for acquiring HCV. HCV-1b was the most predominate genotypes among patients with dental extraction. Persons underwent dental extraction considered as infected as well as an infective (HCV-RNA) source for HCV infection. Dental extraction may be one of the $(40 \%)$ non identifiable routes of viral acquisition. Further studies are needed to clarify this matter.

\section{Competing interests}

The authors declare that they have no competing interests.

\section{Authors' contributions}

\begin{tabular}{|l|c|c|c|c|c|}
\hline Authors' contributions & WA & RAA & NS & YVB & MWA \\
\hline Research concept and design & $\checkmark$ & $\checkmark$ & $\checkmark$ & -- & $\checkmark$ \\
\hline Collection and/or assembly of data & $\checkmark$ & -- & -- & -- & $\checkmark$ \\
\hline Data analysis and interpretation & $\checkmark$ & $\checkmark$ & $\checkmark$ & $\checkmark$ & -- \\
\hline Writing the article & $\checkmark$ & $\checkmark$ & $\checkmark$ & $\checkmark$ & $\checkmark$ \\
\hline Critical revision of the article & $\checkmark$ & $\checkmark$ & $\checkmark$ & $\checkmark$ & -- \\
\hline Final approval of article & $\checkmark$ & $\checkmark$ & $\checkmark$ & $\checkmark$ & $\checkmark$ \\
\hline Statistical analysis & $\checkmark$ & $\checkmark$ & -- & -- & -- \\
\hline
\end{tabular}

\section{Acknowledgement}

We would like to extend our gratitude and appreciation to all administrative staff of the 22 dental clinics in Bagdhdad and all participants of this study. Our extended appreciation to the Ministry of health, Iraq for the approval of this study.

\section{Publication history}

Editor: Mabel M. R. Cordeiro, Federal University of Santa Catarina, Brazil.

EIC: Thimios A. Mitsiadis, University of Zurich, Switzerland.

Received: 23-Apr-2014 Final Revised: 19-May-2014

Accepted: 23-Jun-2014 Published: 04-Jul-2014

\section{References}

1. Baha W, Foullous A, Dersi N, They-they TP, El alaoui K, Nourichafi N, Oukkache B, Lazar F, Benjelloun S, Ennaji MM, Elmalki A, Mifdal H and Bennani $A$. Prevalence and risk factors of hepatitis $B$ and $C$ virus infections among the general population and blood donors in Morocco. BMC Public Health. 2013; 13:50. | Article | PubMed Abstract | PubMed Full Text

2. Nelson PK, Mathers BM, Cowie B, Hagan H, Des Jarlais D, Horyniak D and Degenhardt L. Global epidemiology of hepatitis $B$ and hepatitis $C$ in people who inject drugs: results of systematic reviews. Lancet. 2011; 378:571-83. | Article | PubMed Abstract | PubMed Full Text

3. Alavian SM, Mahboobi $N$ and Karayiannis P. Oral conditions associated with hepatitis C virus infection. Saudi J Gastroenterol. 2013; 19:245-51. | Article | PubMed Abstract | PubMed Full Text

4. Yildirim B, Tahan V, Ozaras R, Aytekin H, Mert A, Tabak F and Senturk H. Hepatitis C virus risk factors in the Turkish community. Dig Dis Sci. 2005; 50:2352-5. | Article | PubMed

5. Paraboni ML, Sbeghen MD, Wolff FH and Moreira LB. Risk factors for infection with different hepatitis $C$ virus genotypes in southern Brazil. ScientificWorldJournal. 2012; 2012:946954. | Article | PubMed Abstract I PubMed Full Text

6. Nokhodian Z, Yazdani MR, Yaran M, Shoaei P, Mirian M, Ataei B, Babak A and Ataie M. Prevalence and Risk Factors of HIV, Syphilis, Hepatitis B and C Among Female Prisoners in Isfahan, Iran. Hepat Mon. 2012; 12:442-7. | Article | PubMed Abstract | PubMed Full Text

7. Januszkiewicz-Lewandowska D, Wysocki J, Rembowska J, Pernak M, Lewandowski K, Nowak T, Nowicka-Kujawska K and Nowak J. Transmission of $\mathrm{HCV}$ infection among long-term hospitalized oncohaematological patients. J Hosp Infect. 2003; 53:120-3. | Article | PubMed

8. Alter MJ. HCV routes of transmission: what goes around comes around. Semin Liver Dis. 2011; 31:340-6. | Article | PubMed

9. Mahboobi N, Agha-Hosseini F, Safari S, Lavanchy D and Alavian SM. Hepatitis B virus infection in dentistry: a forgotten topic. J Viral Hepat. 2010; 17:307-16. | Article | PubMed

10. Mahboobi N, Porter SR, Karayiannis P and Alavian SM. Dental treatment as a risk factor for hepatitis $B$ and $C$ viral infection. A review of the recent literature. J Gastrointestin Liver Dis. 2013; 22:79-86. | Article | PubMed

11. Hahne SJ, Veldhuijzen IK, Wiessing L, Lim TA, Salminen M and Laar M. Infection with hepatitis B and C virus in Europe: a systematic review of prevalence and cost-effectiveness of screening. BMC Infect Dis. 2013; 13:181. | Article | PubMed Abstract | PubMed Full Text

12. Wasley A, Finelli L, Bell $B$ and Alter M. The knowledge and behaviors of HCV-infected persons identified in a seroprevalence survey, USA, 2001-2002. J Clin Virol. 2006; 13:S198-S199.

13. Hutchinson SJ, Roy KM, Wadd S, Bird SM, Taylor A, Anderson E, Shaw L, Codere $\mathrm{G}$ and Goldberg DJ. Hepatitis C virus infection in Scotland: epidemiological review and public health challenges. Scott Med J. 2006; 51:8-15. | Article | PubMed

14. Hahne SJ, De Melker HE, Kretzschmar M, Mollema L, Van Der Klis FR, Van Der Sande MA and Boot HJ. Prevalence of hepatitis B virus infection in The Netherlands in 1996 and 2007. Epidemiol Infect. 2012; 140:1469-80. | Article | PubMed

15. Mahboobi N, Porter SR, Karayiannis $P$ and Alavian SM. Oral fluid and hepatitis A, B and C: a literature review. J Oral Pathol Med. 2012; 41:505-16. | Article | PubMed

16. Stewardson DA, Palenik CJ, McHugh ES and Burke FJ. Occupational exposures occurring in students in a UK dental school. Eur J Dent Educ. 2002; 6:104-13. | Article | PubMed

17. Nagao $Y$ and Sata M. Dental problems delaying the initiation of interferon therapy for HCV-infected patients. Virol J. 2010; 7:192. | Article | PubMed Abstract | PubMed Full Text

18. Coates EA, Brennan D, Logan RM, Goss AN, Scopacasa B, Spencer AJ and Gorkic E. Hepatitis $C$ infection and associated oral health problems. Aust 
Al-Kubaisy et al. Oral Biology and Dentistry 2014,

Dent J. 2000; 45:108-14. | Article | PubMed

19. Henderson L, Muir M, Mills PR, Spence E, Fox R, McCruden EA and Bagg $J$. Oral health of patients with hepatitis $C$ virus infection: a pilot study. Oral Dis. 2001; 7:271-5. | Article | PubMed

20. Modi AA and Liang TJ. Hepatitis C: a clinical review. Oral Dis. 2008; 14:10-4. | Article | PubMed Abstract | PubMed Full Text

21. Simmonds P. Clinical relevance of hepatitis C virus genotypes. Gut. 1997; 40:291-3. | Article | PubMed Abstract | PubMed Full Text

22. Cooreman MP and Schoondermark-Van de Ven EM. Hepatitis $C$ virus: biological and clinical consequences of genetic heterogeneity. Scand $J$ Gastroenterol Suppl. 1996; 218:106-15. | Article | PubMed

23. Mele A, Sagliocca L, Manzillo G, Converti F, Amoroso P, Stazi MA, Ferrigno L, Rapicetta M, Franco E, Adamo B and et al. Risk factors for acute non-A, non- $B$ hepatitis and their relationship to antibodies for hepatitis $C$ virus: a case-control study. Am J Public Health. 1994; 84:1640-3. | Article | PubMed Abstract | PubMed Full Text

24. Ali I, Siddique L, Rehman LU, Khan NU, Iqbal A, Munir I, Rashid F, Khan $\mathrm{SU}$, Attache S, Swati ZA and Aslam MS. Prevalence of HCV among the high risk groups in Khyber Pakhtunkhwa. Virol J. 2011; 8:296. | Article | PubMed Abstract | PubMed Full Text

25. Ugbebor O, Aigbirior M, Osazuwa F, Enabudoso E and Zabayo O. The prevalence of hepatitis $B$ and $C$ viral infections among pregnant women. N Am J Med Sci. 2011; 3:238-41. | Article | PubMed Abstract | PubMed Full Text

26. Vickery K, Tawk HM, Bisset L, Selby W and Cossart YE. Hepatitis C virus infection rates and risk factors in an Australian hospital endoscopy cohort. Aust N Z J Public Health. 2009; 33:442-8. | Article | PubMed

27. Gheorghe L, Csiki IE, lacob S, Gheorghe C, Smira G and Regep L. The prevalence and risk factors of hepatitis $C$ virus infection in adult population in Romania: a nationwide survey 2006 - 2008. J Gastrointestin Liver Dis. 2010; 19:373-9. | Article | PubMed

28. Hasegawa $\mathrm{H}$, Yamada T and Esumi M. Detection of hepatitis $\mathrm{C}$ virus antibody and RNA in hemostatic gauze used for dentistry. Infect Control Hosp Epidemiol. 2003; 24:137-9. | Article | PubMed

29. Tahan V, Karaca C, Yildirim B, Bozbas A, Ozaras R, Demir K, Avsar E, Mert A, Besisik F, Kaymakoglu S, Senturk H, Cakaloglu Y, Kalayci C, Okten $A$ and Tozun N. Sexual transmission of HCV between spouses. Am J Gastroenterol. 2005; 100:821-4. | Article | PubMed

30. Dusheiko G, Schmilovitz-Weiss H, Brown D, McOmish F, Yap PL, Sherlock $S$, Mclntyre $N$ and Simmonds $P$. Hepatitis $C$ virus genotypes: an investigation of type-specific differences in geographic origin and disease. Hepatology. 1994; 19:13-8. | Article | PubMed

31. Al-Faleh $\mathrm{FZ}$ and Ramia S. Hepatitis C virus (HCV) infection in Saudi Arabia: A review. Ann Saudi Med. 1997; 17:77-82. | Pdf | PubMed

32. Darwish $M$, Faris R, Clemens J, Rao $M$ and Edelman R. Hepatitis $C$ virus. Lancet. 1995; 345:190-191.

33. Zein NN and Persing DH. Hepatitis C genotypes: current trends and future implications. Mayo Clin Proc. 1996; 71:458-62. | Article | PubMed

34. Alashek $W$ and Altagdi $M$. Risk factors and genotypes of hepatitis $C$ virus infection in libyan patients. Libyan J Med. 2008; 3:162-5. | Article | PubMed Abstract I PubMed Full Text

35. Lin HH, Kao JH, Mizokami M, Huang SC, Chen PJ and Chen DS. Serotypes, genotypes and levels of hepatitis $C$ viremia in pregnant women in Taiwan. J Formos Med Assoc. 1996; 95:429-34. | Article | PubMed

36. Love A, Sigurdsson JR, Stanzeit B, Briem H, Rikardsdottir $\mathrm{H}$ and Widell $A$. Characteristics of hepatitis $C$ virus among intravenous drug users in Iceland. Am J Epidemiol. 1996; 143:631-6. | Article | PubMed

37. Pawlotsky JM, Prescott L, Simmonds P, Pellet $C$, Laurent-Puig $P$, Labonne C, Darthuy F, Remire J, Duval J, Buffet C, Etienne JP, Dhumeaux D and Dussaix E. Serological determination of hepatitis $C$ virus genotype: comparison with a standardized genotyping assay. J Clin Microbiol. 1997; 35:1734-9. | Article | PubMed Abstract | PubMed Full Text

38. Yuki N, Hayashi N, Moribe T, Matsushita $Y$, Tabata $T$, Inoue $T$, Kanazawa $\mathrm{Y}$, Ohkawa K, Kasahara A, Fusamoto $\mathrm{H}$ and Kamada T. Relation of disease activity during chronic hepatitis $\mathrm{C}$ infection to complexity of hypervariable region 1 quasispecies. Hepatology. 1997; 25:439-44. |
Article I PubMed

39. Pistello M, Menzo S, Giorgi M, Da Prato L, Cammarota G, Clementi M and Bendinelli M. Competitive polymerase chain reaction for quantitating feline immunodeficiency virus load in infected cat tissues. Mol Cell Probes. 1994; 8:229-34. | Article | PubMed

40. Zhang ZX, Chen M, Hultgren C, Birkett A, Milich DR and Sallberg M. Immune responses to the hepatitis $C$ virus NS4A protein are profoundly influenced by the combination of the viral genotype and the host major histocompatibility complex. J Gen Virol. 1997; 78 ( Pt 11):2735-46. | Article I PubMed

41. Doi H, Apichartpiyakul C, Ohba KI, Mizokami M and Hotta H. Hepatitis C virus (HCV) subtype prevalence in Chiang Mai, Thailand, and identification of novel subtypes of HCV major type 6. J Clin Microbiol. 1996; 34:569-74. | Article | PubMed Abstract | PubMed Full Text

42. Sanchez-Quijano A, Abad MA, Torronteras R, Rey C, Pineda JA, Leal M, Macias J and Lissen E. Unexpected high prevalence of hepatitis $C$ virus genotype 4 in Southern Spain. J Hepatol. 1997; 27:25-9. | Article | PubMed

43. Mondelli MU, Cerino A, Lisa A, Brambilla S, Segagni L, Cividini A, Bissolati M, Missale G, Bellati G, Meola A, Bruniercole B, Nicosia A, Galfre G and Silini $E$. Antibody responses to hepatitis $C$ virus hypervariable region 1: evidence for cross-reactivity and immune-mediated sequence variation. Hepatology. 1999; 30:537-45. | Article | PubMed

\section{Citation:}

Al-Kubaisy W, Al-Naggar RA, Shamsidah Ni N, Bobryshev YV and Al-Kubaisy MW. Is dental extraction a risk factor for contracting $\mathrm{HCV}$ infection: Abs, RNA and genotype detection. Oral Biol Dent. 2014; 2:7. http://dx.doi.org/10.7243/2053-5775-2-7 